\title{
Saproxylic species are linked to the amount and isolation of dead wood across spatial scales in a beech forest
}

\author{
Elena Haeler (1) - Ariel Bergamini (1) - Stefan Blaser • Christian Ginzler (1) • \\ Karin Hindenlang • Christine Keller • Thomas Kiebacher • Urs G. Kormann (D) \\ Christoph Scheidegger (D) - Ronald Schmidt - Jonas Stillhard (D) \\ Alexander Szallies • Loïc Pellissier (i) Thibault Lachat $(\mathbb{D}$
}

Received: 30 November 2019/Accepted: 14 September 2020/Published online: 3 October 2020

(C) The Author(s) 2020

\begin{abstract}
Context Dead wood is a key habitat for saproxylic species, which are often used as indicators of habitat quality in forests. Understanding how the amount and spatial distribution of dead wood in the landscape affects saproxylic communities is therefore important for maintaining high forest biodiversity.

Objectives We investigated effects of the amount and isolation of dead wood on the alpha and beta diversity of four saproxylic species groups, with a focus on how the spatial scale influences results.

Methods We inventoried saproxylic beetles, wood-

Electronic supplementary material The online version of this article (https://doi.org/10.1007/s10980-020-01115-4) contains supplementary material, which is available to authorized users.
\end{abstract}

E. Haeler $(\bowtie) \cdot$ U. G. Kormann · T. Lachat

Forest Sciences, School of Agricultural, Forest and Food

Sciences HAFL, Bern University of Applied Sciences,

3052 Zollikofen, Switzerland

e-mail: elena.haeler@bfh.ch

E. Haeler · L. Pellissier

Landscape Ecology, Institute of Terrestrial Ecosystems,

ETH Zürich, 8092 Zurich, Switzerland

E. Haeler · A. Bergamini - S. Blaser .

C. Ginzler · C. Keller · T. Kiebacher .

C. Scheidegger · J. Stillhard - L. Pellissier - T. Lachat Swiss Federal Institute for Forest, Snow and Landscape Research WSL, 8903 Birmensdorf, Switzerland inhabiting fungi, and epixylic bryophytes and lichens on 62 plots in the Sihlwald forest reserve in Switzerland. We used GLMs to relate plot-level species richness to dead wood amount and isolation on spatial scales of 20-200 m radius. Further, we used GDMs to determine how dead wood amount and isolation affected beta diversity.

Results A larger amount of dead wood increased beetle richness on all spatial scales, while isolation had no effect. For fungi, bryophytes and lichens this was only true on small spatial scales. On larger scales of our study, dead wood amount had no effect, while greater isolation decreased species richness. Further, we found no strong consistent patterns explaining beta diversity.

K. Hindenlang $\cdot$ R. Schmidt

Stiftung Wildnispark Zürich, 8135 Sihlwald, Switzerland

T. Kiebacher

Department of Systematic and Evolutionary Botany,

University of Zurich UZH, 8008 Zurich, Switzerland

U. G. Kormann

Swiss Ornithological Institute, 6204 Sempach, Switzerland

A. Szallies

Institute of Natural Resource Sciences IUNR, School of Life Sciences and Facility Management, 8820 Wädenswil, Switzerland 
Conclusions Our multi-taxon study shows that habitat amount and isolation can strongly differ in the spatial scale on which they influence local species richness. To generally support the species richness of different saproxylic groups, dead wood must primarily be available in large amounts but should also be evenly distributed because negative effects of isolation already showed at scales under $100 \mathrm{~m}$.

Keywords Biodiversity conservation .

Connectivity · Forest management · Habitat amount

hypothesis $\cdot$ Scale dependence

\section{Introduction}

Biodiversity is declining globally as a consequence of climate and land-use change (Sala et al. 2000; Rockström et al. 2009; Steffen et al. 2015; IPBES 2019). Forests cover about one-third of the global total landmass (FAO 2010; FOREST EUROPE 2015), and in temperate regions a high proportion of species depend on them, e.g. around $40 \%$ of the species in Switzerland (Imesch et al. 2015; Rigling and Schaffer 2015). Forest management therefore plays an essential role in the conservation of biodiversity (FAO 2010). While tropical forests are disappearing rapidly, European forests have been expanding since the 1990s but are often intensively managed (Bryant et al. 1997; FAO 2010). This leads to a severe underrepresentation of old successional stages in many regions (Vilén et al. 2012) and a decline of species that depend on old-growth forest characteristics such as large amounts of dead wood and old trees (Brunet et al. 2010; Paillet et al. 2010; Eckelt et al. 2018). In temperate and boreal regions, $20-25 \%$ of forest species depend on the availability of dead wood (= saproxylic species; Stokland et al. 2012), which makes it a key element for biodiversity conservation in forests (MCPFE 2003; Stokland et al. 2012). Preserving biodiversity consequently requires not only the presence of forested area, but also management that preserves such habitats within forests. For the development of appropriate management concepts, research on key elements supporting biodiversity is needed.

Conservation measures often aim to increase habitat availability for species, which can be reached through an increased habitat amount (Margules and
Pressey 2000). Complementing the amount, the spatial distribution of habitats is regarded as another key factor to preserve species (Tscharntke et al. 2012). To improve conservation measures, it is therefore also necessary to understand how habitat configuration fosters biodiversity. MacArthur and Wilson (1967) developed the theory of island biogeography, stating that the species richness of an island depends on its size and isolation, which has implication in conservation when managing habitats. In particular, this concept has been adopted to manage patches of habitat in fragmented terrestrial ecosystems (Tscharntke et al. 2012; Fahrig 2013; Watling et al. 2020). However, Fahrig (2013) questioned this application and proposed the 'habitat amount hypothesis', stating that in a 'local landscape' (of appropriate size) only the habitat amount affects species richness. According to this hypothesis, species richness is not influenced by the isolation and the size of the 'local patch' where species are sampled, but rather by the 'sample area effect' driving the two effects (for details see Fahrig 2013). While some studies testing the habitat amount hypothesis have found support for it (e.g. birds: De Camargo et al. 2018; small mammals: Melo et al. 2017; macro-moths: Merckx et al. 2019; saproxylic beetles: Seibold et al. 2017; multiple species: Watling et al. 2020), others have rejected it (e.g. plants: Evju and Sverdrup-Thygeson 2016; Lindgren and Cousins 2017; micro-arthropods: Haddad et al. 2016; birds: Kormann et al. 2018) or found different results for different taxonomic groups (frogs and reptiles: Pulsford et al. 2017). Studies testing the habitat amount hypothesis need to disentangle habitat amount and isolation, which is not always easy in natural ecosystems, as the two factors are often highly correlated (Fahrig 2017). Besides species richness, habitat amount and isolation might also affect community composition (beta diversity). Forest management is known to change species assemblages (Aude and Poulsen 2000; Müller et al. 2008; Gossner et al. 2013; Bässler et al. 2014), partly due to altering the habitat availability. Further, different taxonomic groups may not react in the same way, which requires system- and taxon-specific evaluations of the relationship between biodiversity and habitat amount and isolation.

Comparing the responses of multiple taxonomic groups to the same ecological gradient may provide insights on how species groups with different requirements are affected by the amount and spatial 
distribution of a given habitat. One may expect taxonomic groups to vary in their response to habitat amount and isolation, for example depending on their dispersal ability, which differs not only between but also within species groups (Komonen and Müller 2018) or even single species (Ronnås et al. 2017). Consequently, selecting the appropriate size of the 'local landscape' as mentioned by Fahrig (2013), remains complicated. Only testing responses on one spatial scale might therefore mean that divergent patterns on other scales are overlooked (see Fig. 1). Some previous studies testing the habitat amount hypothesis have considered more than one spatial scale, but the focus has been on the effects of local patch size compared to that of the total habitat amount in the surroundings (Seibold et al. 2017) and fragmentation (Bosco et al. 2019). Habitat isolation, defined as a measure of distance between the sampling site and habitats in the landscape, has not been investigated or, as in a study by Melo et al. (2017), has only been calculated once on a
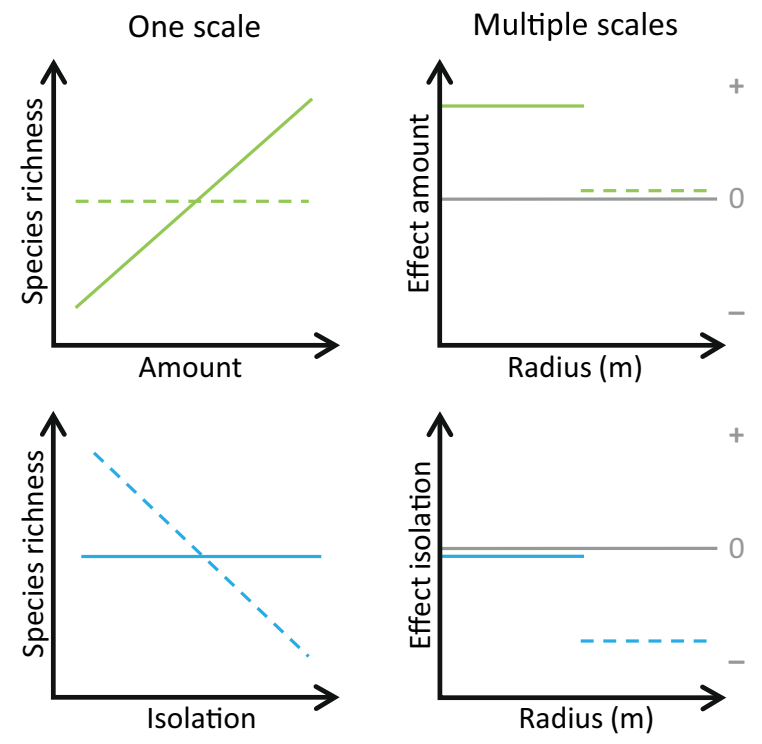

Fig. 1 Possible outcomes showing if the relationship of species richness with dead wood amount (green, top) and isolation (blue, bottom) follow the 'habitat amount hypothesis' (HAH). Solid line $=$ consistent with HAH. Dashed line = not consistent with HAH. Left: When considering one scale, a positive effect of amount and no effect of isolation would support the HAH on this scale. Right: The outcome of single scales, i.e. the coefficient estimates of amount and isolation, can be plotted against the tested radii. Here the HAH is supported on smaller scales (positive estimates for amount, no effect of isolation), while it is not supported on larger scales (no effect of habitat amount, negative effect of isolation) small scale and not on all scales considered. More studies that include different spatial scales as well as multiple species groups are needed to evaluate the generality of patterns.

In this study, we tested in a forest reserve if habitat amount and/or isolation on different spatial scales (20-200 $\mathrm{m}$ radius) are important for biodiversity. In forests, dead wood pieces represent habitat patches with defined borders, scattered in a landscape matrix. We include four species groups, which all depend on dead wood as habitat but have different dispersal strategies and abilities: saproxylic beetles, wood-inhabiting fungi, epixylic bryophytes and epixylic lichens. These species groups make up a considerable part of the total biodiversity in temperate forest systems, are among the groups which show the highest sensitivity to habitat changes caused by forestry (Brunet et al. 2010; Paillet et al. 2010), and are therefore frequently used as indicators for near natural and unmanaged forests (Stokland et al. 2012; Lachat et al. 2012). Intensive management typically reduces the amount and diversity of dead wood, and as a result many species that depend on dead wood are threatened (Martikainen et al. 2000; Grove 2002). Conservation strategies often focus on the amount of dead wood (Jonsson et al. 2005; Müller and Bütler 2010; Halme et al. 2013; Seibold et al. 2015), but some do take the spatial distribution of habitats into account (e.g. Mason and Zapponi 2016). To consider both aspects, we aimed to answer the following questions:

(1) How is the species richness of saproxylic species associated with dead wood amount and isolation?

(2) Do the four taxonomic groups show a similar response to dead wood amount and isolation, and are these patterns consistent across different spatial scales?

(3) Is there a consistent relationship between dead wood amount and isolation and the beta diversity of assemblages across the four investigated taxonomic groups?

\section{Material and methods}

\section{Study area}

The study was carried out in the Sihlwald forest reserve $\left(47^{\circ} 15^{\prime} 20^{\prime \prime} \mathrm{N}, 8^{\circ} 33^{\prime} 00^{\prime \prime} \mathrm{E}\right)$, which is, with 
around 1100 ha, the largest continuous unmanaged beech forest in the Swiss lowlands (see Fig. S1 in the Online Resource). The main part of the reserve lies on the northeast-exposed west side of the Sihl river at an elevation of 467-915 $\mathrm{m}$ a.s.l. The forest is dominated by European beech (Fagus sylvatica) and Norway spruce (Picea abies) (Brang et al. 2011; Brändli et al. 2020). Sihlwald is a young forest reserve (established in 2007) still recovering from over 500 years of intensive management, but there are stands that were left untouched for several decades. Management ceased in 2000, and since 2010 the forest has been protected as a 'park of national importance' (MCPFEcategory: 1.2).

Plot selection and dead wood map

Our study was based on a subsample of 62 plots selected from 503 permanent forest inventory plots $(100 \times 200 \mathrm{~m}$ raster $)$ established in 1981 and remeasured in 1990, 2003 and 2017. In the latest inventory, all trees with a diameter at breast height $(\mathrm{DBH}=130$ $\mathrm{cm}$ ) $\geq 7 \mathrm{~cm}$, tree-related microhabitats (for details see Table S1 in the Online Resource) and dead wood were recorded on circular plots of $300 \mathrm{~m}^{2}$ (Brändli et al. 2020). As the natural vegetation of Sihlwald is beech forest and because the focus of our study was dead wood, we only considered plots in mature stands with at least $50 \%$ deciduous trees for the selection. This pre-selection was performed using two standscale habitat mappings based on aerial imagery [Canton of Zurich (2001) and Wildnispark Zürich (2005)] and resulted in 208 plots.

For the selection of the plots along two orthogonal gradients of dead wood amount and isolation, we created a map of the lying dead wood for the whole perimeter of Sihlwald forest. Following the protocol of Leiterer et al. (2013) a first map was created based on LiDAR data gathered in 2014 (LiDAR laserscanning geodata 1.2.2015, Geographic Information System of the Canton of Zurich). We complemented the LiDARbased map by digitizing lying dead wood from stereoscopic aerial imagery acquired under leaf-off conditions in 2013 (ADS80 stereo aerial photographs 17.4.2013, swisstopo). We were not able to determine the diameter of the dead wood pieces from the LiDAR data or the stereoscopic aerial images, and we therefore mapped the dead wood as lines.
Based on the dead wood map, dead wood amount and isolation were estimated within a $40 \mathrm{~m}$ radius from the center of every plot remaining after the preselection $(\mathrm{N}=208)$. This radius was chosen as the 'local landscape' because the correlation between dead wood amount and species richness of saproxylic beetles was found to be the strongest in a $40 \mathrm{~m}$ radius in a recent study from a temperate European forest (Seibold et al. 2017). We used the summed length of all mapped dead wood pieces within the circle of $40 \mathrm{~m}$ radius (Fig. 2) as our estimator of dead wood amount. For dead wood extending beyond the circle, only the part within the circle was considered (see light green lines in Fig. 2). For our estimator of isolation, we calculated the median distance to the plot center of all mapped dead wood pieces within the $40 \mathrm{~m}$ radius. We then selected the 62 plots using a stratified random selection along the gradients of dead wood amount and isolation. The minimum distance between two plots was $100 \mathrm{~m}$ (Fig. S1).

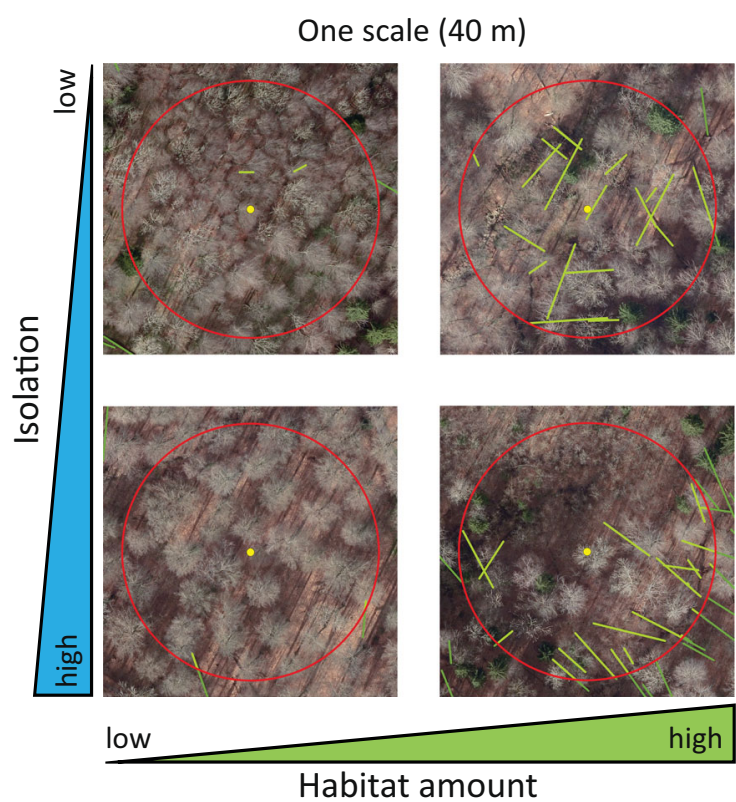

Fig. 2 Four of the 62 selected plots, which differ in dead wood amount (increasing from left to right) and isolation (increasing from top to bottom) on a radius of $40 \mathrm{~m}$ around the plot center. Each plot center is indicated by a yellow point. Mapped dead wood pieces are shown as green lines (light and dark green). The circle (solid line) is the $40 \mathrm{~m}$ radius used for selection of the plots. Only the parts of dead wood pieces that were within the radius were used to calculate the amount (light green lines). Source: aerial image 17.03.2014, Osterwalder, Lehmann Ingenieure und Geometer AG 
Sampling methods

Beetles were collected from the beginning of May until the middle of August 2017 with two flight interception traps $\left(\right.$ Polytrap $^{\mathrm{TM}}$ ) per plot. The traps were emptied every 3 rd week. Both traps were situated within a radius of $17.8 \mathrm{~m}$ from the plot center and close to a potential habitat, i.e. dead wood (preferably of beech). Species were identified as saproxylic or non-saproxylic based on a list compiled by Müller et al. (2013). Non-saproxylic species were excluded from further analyses. We pooled the species lists of the two traps from each plot for the analyses.

Wood-inhabiting fungi were examined on a 1000 $\mathrm{m}^{2}$ circle (17.8 $\mathrm{m}$ radius) centered around the plot center. Fungi were recorded based on the occurrence of fruiting bodies: once in autumn (2016), which is the time of year when most fungi have fruiting bodies, and once in June (2017) to detect species with a different phenology. Basidiomycetes and Ascomycetes with fruiting bodies $>0.5 \mathrm{~cm}$ in diameter were included.

Bryophytes and lichens were examined on a $314 \mathrm{~m}^{2}$ circle (10 m radius) around the plot center from March to June 2017 and from November 2016 to June 2017, respectively. All species were recorded on all substrates, but only epixylic species were included in further analyses. Epixylic bryophytes and lichens were selected on the one hand based on trait information (bryophytes: Landolt et al. 2010; lichens: Stofer et al. 2006; Wirth 2010). On the other hand, species were considered epixylic when they were found on dead wood and had supposedly established on the already dead tissue. These species might not be obligatory epixylic, but they still used the dead wood as habitat. Species that were found on still intact bark of dead wood but that probably established and grew on the tree when it was still alive were considered epiphytic and not epixylic and were therefore excluded from the analyses.

For a detailed examination of fungi, bryophytes and lichens, two dead wood pieces were selected at each plot: the largest log and one randomly selected piece with a diameter between 7 and $12 \mathrm{~cm}$. The two dead wood pieces were located at least partly within the $17.8 \mathrm{~m}$ radius around the plot center. For the analyses the species lists of the plot and the dead wood pieces were pooled for each of the three species groups.
Dead wood amount and isolation

The estimators for dead wood amount and isolation for different spatial scales were derived from the dead wood map in the same way as for the $40 \mathrm{~m}$ radius used for plot selection. Dead wood amount was calculated as the summed length of all mapped dead wood pieces and isolation was calculated as the median distance from these dead wood pieces to the plot center. For testing the habitat amount hypothesis, Fahrig (2013) proposed using nearest-neighbor distance as the estimator for isolation. As we worked on different spatial scales, we needed a scale-sensitive estimator for isolation which also describes differences in the spatial arrangement of dead wood on larger scales. We therefore used the median distance as a comparable substitute. We calculated the two estimators for each of 19 concentric circles around every plot center $(\mathrm{N}=62)$, with the radius of the circles ranging from 20 to $200 \mathrm{~m}$ in $10 \mathrm{~m}$ steps. With Pearson's r values between -0.3 and 0.01 on the different scales, the two estimators are not correlated (see Fig. S2 in the Online Resource).

Isolation was not included for analyses at a radius of $20 \mathrm{~m}$ because the species data were collected in the $1000 \mathrm{~m}^{2}$ area (radius $=17.8 \mathrm{~m}$ ). This radius of $17.8 \mathrm{~m}$ included the species inventory on the plot, the two dead wood pieces and the two beetle traps. Calculating isolation as the median distance of all the mapped dead wood pieces to the plot center within the $20 \mathrm{~m}$ radius was therefore not reasonable.

\section{Environmental variables}

Information about the forest structure on the plot was calculated from the forest inventory (basal area per ha, trees per ha, trees with $\mathrm{DBH}>70 \mathrm{~cm}$, maximum $\mathrm{DBH}$, tree species diversity, proportion coniferous trees, tree microhabitats, dead wood diversity) and LiDAR data (tree height, vertical structure). Measurements from the forest inventory, where dead wood was recorded using a transect method (Böhl and Brändli 2007), allowed for the computation of dead wood diversity expressed as the Shannon index for dead wood types based on tree species, diameter class and decay stage. From the transect data the dead wood volume on the plot was estimated following Böhl and Brändli (2007). This volume estimator strongly correlated with the dead wood amount derived from the 
dead wood map on small spatial scales (Table S2). We therefore only used the amount derived from the map as our estimator of total dead wood amount for the analyses on all scales, although the volume of coniferous dead wood on the plot was used for the analyses of beta diversity.

Besides forest structure, we measured two abiotic variables. Temperature was measured with one HOBO Pendant ${ }^{\circledR}$ temperature data logger (UA-001-08; Onset Computer Corporation) installed on each plot. Light availability was calculated with the software Hemisfer (Schleppi et al. 2007; Thimonier et al. 2010) from synthetic hemispherical images derived from the LiDAR data (Moeser et al. 2015; Zellweger et al. 2019).

All environmental variables were independent of scale, while the values for dead wood amount and median distance changed with spatial scale. Details on all variables are provided in the Online Resource (Table S1).

\section{Species richness}

To assess the response of species richness to dead wood amount and isolation across spatial scales, we first specified a full model for every radius (20-200 m, $10 \mathrm{~m}$ steps) for each taxonomic group. Species richness was the response variable in the models. Dead wood amount (20-200 m radius) and isolation (30-200 m radius) from the respective radius and-to 'filter out' their potential effects-the scale-independent environmental variables were used as explanatory variables (Table S1). All explanatory variables were centered at 0 and scaled to $\mathrm{SD}=1$. All statistical analyses were performed using R Version 3.5.2 (R Core Team 2018).

We used generalized linear models (GLMs) with a negative binomial distribution (function glm.nb, package 'MASS'; Ripley et al. 2018), as initial analysis with poisson models showed overdispersion. We then performed model selection based on the corrected Akaike information criterion (AICc) to identify the best model containing both focal variables (dead wood amount and isolation) on each scale using the function dredge (package 'MuMIn'; Barton 2018). The best model for different scales could-besides dead wood amount and isolation-include different variables. We aimed at assessing the relative importance of dead wood amount and isolation across spatial scales and did not assess effect size. For every species group and every radius, we report coefficient estimates, standard errors, $\mathrm{z}$-values and p-values of the best model in the Online Resource (Tables S3-S6). Additionally, we present the $\mathrm{R}^{2}$ values (likelihood-ratio based) in Table S7.

\section{Beta diversity}

We calculated the Sørensen index (total beta diversity) to determine the dissimilarities between communities on the plot. For each of the species groups, we calculated the multi-site dissimilarities (beta.SOR, beta.SIM, beta.SNE) with the function beta.multi and averaged the pairwise dissimilarities (beta.sor, beta.sim, beta.sne), calculated with the function beta.pair (R package 'betapart'; Baselga et al. 2017).

We performed generalized dissimilarity modeling (GDM) to analyze which factors explain changes in community composition, represented by the Sørensen index (beta.sor) ( $g d m$ function, package ' $g d m$ '; Manion et al. 2018). We used the same explanatory variables as for the analyses of species richness (Table S1), but we added one variable describing the volume of coniferous dead wood on the plot (derived from the inventory data) because communities of saproxylic species are known to differ between deciduous and coniferous dead wood. Further, the geographic distance between plots was included as a variable in the models.

The GDMs were performed on every scale between 20 and $200 \mathrm{~m}$ radius (10 $\mathrm{m}$ steps), keeping the environmental variables unchanged while using the values for dead wood amount and isolation for the respective radius. Using the full models including all predictor variables, we calculated the importance of each variable in 50 permutations ( $g$ dm.varImp function, package 'gdm'; Manion et al. 2018). Based on these results, we only included variables explaining more than $1 \%$ of deviance on at least one scale to obtain less complex models for each species group. The environmental variables included in the small models were therefore the same for all the scales within each species group. Dead wood amount (20-200 $\mathrm{m}$ radius) and isolation (30-200 m radius) were always included, regardless of their importance. We then estimated overall deviance explained, variable importance and p-values once more for the small 
models on all scales with the gdm.varImp function (see Online Resource, Tables S9-S12).

\section{Results}

In total, we found 327 beetle, 387 fungal, 74 bryophyte and 35 lichen species associated with dead wood on the 62 plots (Table 1). The proportion of species that were only found on one plot ranged from $21 \%$ (beetles) to $46 \%$ (lichens).

Species richness

For each species group, we found significant positive relationships between dead wood amount and species richness, but the species groups differed in the spatial scales at which this effect manifested (Fig. 3, Tables S3-S6). For fungi, bryophytes and lichens, significant positive effects of dead wood amount occurred at smaller radii (up to $60 \mathrm{~m}$ for fungi, $40 \mathrm{~m}$ for bryophytes, $80 \mathrm{~m}$ for lichens) but not at larger radii (Fig. 3b-d). The strongest effects were found at $30 \mathrm{~m}$ for fungi, $40 \mathrm{~m}$ for bryophytes and $50 \mathrm{~m}$ for lichens. In contrast, species richness of beetles increased with increasing dead wood amount on all spatial scales. Further, the magnitude of this effect was constant across scales (Fig. 3a) and the effect was significant at all radii.

The responses to isolation showed different patterns for fungi, bryophytes and lichens compared with that for the beetles (Fig. 3). We found fewer species of fungi, bryophytes and lichens with increasing isolation on larger scales. The negative relationship started being significant on scales between 60 and $100 \mathrm{~m}$ and despite not being significant on all larger scales, the pattern remained consistent for fungi, bryophytes and lichens. In contrast, for beetles there was no consistent relationship between species richness and isolation on any scale.

The proportion of variance explained by the best model on each scale, ranged from $30.3 \%(50 \mathrm{~m})$ to $34.9 \%(140 \mathrm{~m})$ for beetles, from $31.4 \%(70 \mathrm{~m})$ to $41 \%$ $(40 \mathrm{~m})$ for fungi, from $36.7 \%(150 \mathrm{~m})$ to $45.3 \%$ $(30 \mathrm{~m})$ for bryophytes and from $20.1 \%(180 \mathrm{~m})$ to $40.5 \%(130 \mathrm{~m})$ for lichens (values for all scales are reported in Table $\mathrm{S} 7$ ).

\section{Beta diversity}

Species assemblages of all taxonomic groups showed a similar and high multi-site community dissimilarity (around 95\%), and most of the dissimilarity (over 90\%) was due to species turnover and not nestedness (Tables 2 and S8). When looking at the averaged pairwise dissimilarity, the groups showed larger differences. While the average dissimilarity between two plots was lowest for beetles (44\%), it was highest for fungi $(82.4 \%)$.

The generalized dissimilarity models (GDMs) explained up to $13.5 \%$ of the difference in community composition for lichens and up to $16.2 \%$ for beetles. For fungi (max. 6.2\%) and bryophytes (max. 3.3\%) this fraction was much lower (Table 2, values for all scales see Table S9).

The effect of dead wood amount on community composition was only significant for fungi on larger spatial scales $(130 \mathrm{~m}, 170 \mathrm{~m}$ and $200 \mathrm{~m})$ (Fig. 4b,

Table 1 Species richness of the four species groups on the 62 plots

\begin{tabular}{|c|c|c|c|c|}
\hline & Saproxylic beetles & Wood-inhabiting fungi & Epixylic bryophytes & Epixylic lichens \\
\hline \multicolumn{5}{|l|}{ Total } \\
\hline Number of species & 327 & 387 & 74 & 35 \\
\hline Singletons (percent) & $67(20.5 \%)$ & $166(42.9 \%)$ & $18(24.7 \%)$ & $16(45.7 \%)$ \\
\hline \multicolumn{5}{|l|}{ Per plot } \\
\hline Min. & 41 & 7 & 4 & 0 \\
\hline Mean \pm SD & $79.6 \pm 15.8$ & $29.1 \pm 10.5$ & $15.6 \pm 5.8$ & $2.3 \pm 1.9$ \\
\hline Max. & 116 & 55 & 31 & 8 \\
\hline
\end{tabular}

Species identified only to the genus level were excluded. Singletons were defined as species found on only a single plot, independent of their abundance on that plot 

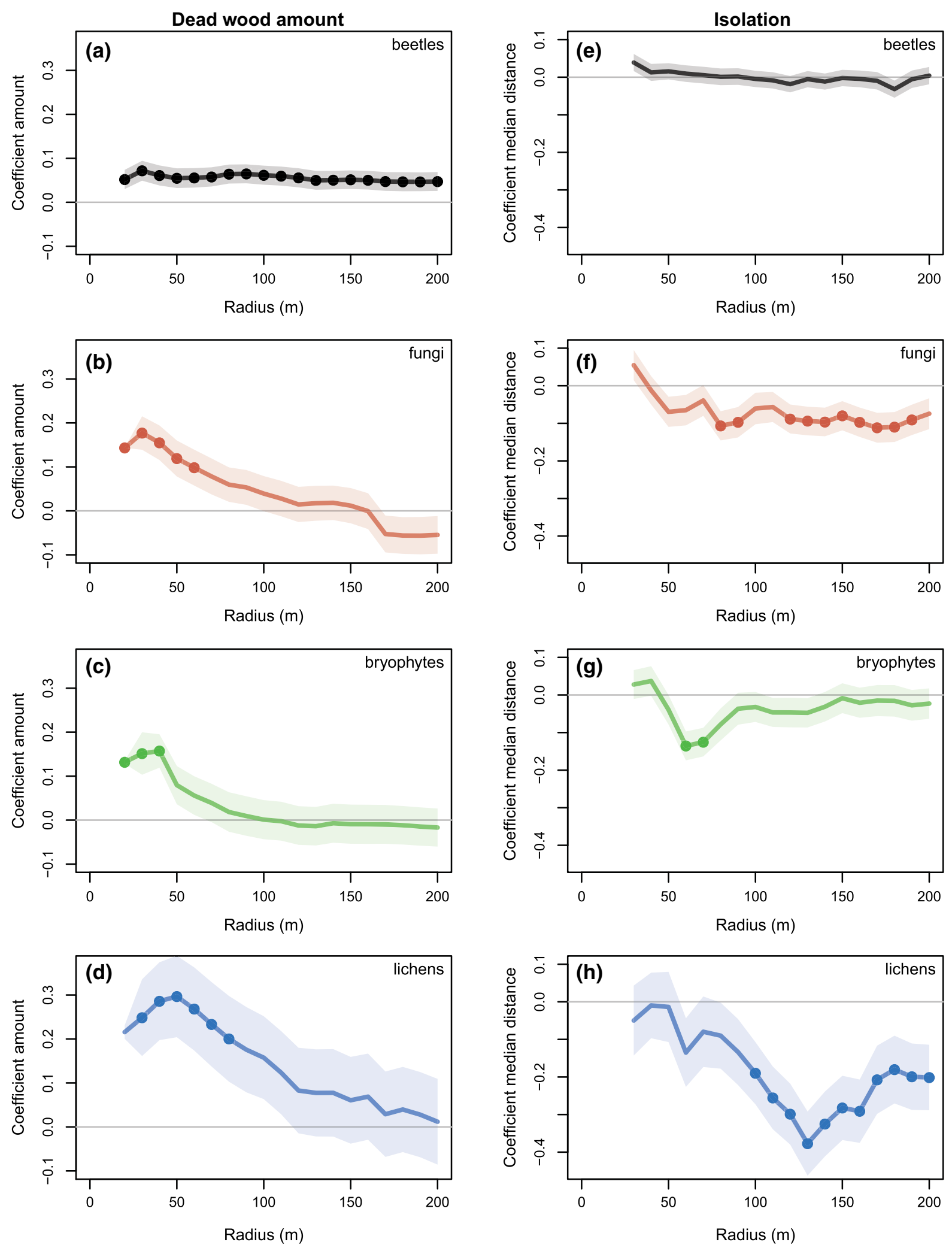
4Fig. 3 Coefficient estimates of dead wood amount (summed length of dead wood pieces; left) and isolation (median distance of dead wood pieces to the plot center; right) derived for beetles $(\mathbf{a}, \mathbf{e})$, fungi $(\mathbf{b}, \mathbf{f})$, bryophytes $(\mathbf{c}, \mathbf{g})$ and lichens $(\mathbf{d}, \mathbf{h})$ from the best model of the respective scale. line $=$ coefficient estimate, dot $=\mathrm{p}<0.05$, band $=$ standard error

Table S11). The species assemblage changed with an increasing amount of dead wood but reached a plateau soon thereafter: a larger amount after this point did not lead to a different community composition. The effect of isolation on community composition was only significant for the two species groups with the highest explained variance in the GDM: once for lichens $(50 \mathrm{~m})$ and twice for beetles $(170 \mathrm{~m}$ and $180 \mathrm{~m})$ (Fig. 4, Tables S10 and S13).

\section{Discussion}

The diversity of the four studied species groups (saproxylic beetles, wood-inhabiting fungi, and epixylic bryophytes and lichens) was associated with dead wood amount and isolation on different scales. Even though the species groups differed in total species numbers, with high numbers for beetles (327) and fungi (387) and much lower numbers for bryophytes (74) and lichens (35), we found similarities in their responses to amount and isolation. Contrasting patterns became apparent on different spatial scales for the four taxonomic groups, highlighting the importance of multi-scale testing and a multi-species approach. In particular, we found that the amount of dead wood was important in explaining the diversity on a small spatial scale, while isolation became more important on larger spatial scales.

Species richness increased with dead wood amount across a range of spatial scales. On small scales (radius $<60 \mathrm{~m}$ ), our results were similar for the taxonomic groups and all four groups showed a positive relationship. Dead wood amount was always more important than isolation, which is consistent with the habitat amount hypothesis (Fahrig 2013). A positive relationship at the $20 \mathrm{~m}$ radius might be partly explained by the larger amount of local dead wood that was actually examined for fungi, bryophytes and lichens (species-area relationship). However, the coefficients of dead wood amount did not peak at $20 \mathrm{~m}$ for any of the groups, showing that this should not interfere with our results. Our results are further consistent with previous studies on saproxylic species showing a positive effect of dead wood in the immediate surroundings on species richness (e.g. Lassauce et al. 2011; Boch et al. 2013; Müller et al. 2015; Seibold et al. 2017). This suggests that the studied taxonomic groups are not dispersal limited on smaller spatial scales.

Different responses of the species groups to dead wood amount and isolation were only evident on larger scales. As especially the difference of beetles compared with fungi, bryophytes and lichens became apparent (Fig. 3), the responses might be explained by different dispersal abilities and strategies.

For beetles the habitat amount was always more important than its spatial distribution. The coefficient

Table 2 Dissimilarities of community composition of the four species groups

\begin{tabular}{lllll}
\hline & Saproxylic beetles & Wood-inhabiting fungi & Epixylic bryophytes & Epixylic lichens \\
\hline Multi-site dissimilarity $\beta_{\text {SOR }}$ & $93.5 \%$ & $96.9 \%$ & $94.3 \%$ & $96 \%$ \\
Pairwise dissimilarity $\beta_{\text {sor }}$ & $44 \pm 5.4 \%$ & $82.4 \pm 8.9 \%$ & $50.1 \pm 12.2 \%$ & $73.4 \pm 27.4 \%$ \\
Explained variance $(\mathrm{GDM})^{\mathrm{a}}$ & & & & \\
Min & $13.5 \%(120 \mathrm{~m})$ & $3.6 \%(40 \mathrm{~m})$ & $2.1 \%(150 \mathrm{~m})$ & $10.9 \%(90 \mathrm{~m})$ \\
Max & $16.2 \%(170 \mathrm{~m})$ & $6.2 \%(180 \mathrm{~m})$ & $3.3 \%(60 \mathrm{~m})$ & $13.5 \%(60 \mathrm{~m})$ \\
\hline
\end{tabular}

Multi-site dissimilarity (rounded): overall dissimilarity (Sørensen index). Pairwise dissimilarity (rounded): mean of total dissimilarities between two plots \pm standard deviation (SD). Explained variance (rounded): proportion of the variance in community composition that could be explained by the generalized dissimilarity models (small models). Shown are the radii (m in brackets) with the lowest and the highest proportion of explained variance

${ }^{\mathrm{a}}$ Values from $20 \mathrm{~m}$ radius were excluded, as the models include one variable less (isolation); for fungi (3.6\%), bryophytes (2.1\%) and lichens $(10.7 \%)$ explained variance was the lowest on $20 \mathrm{~m}$ radius 

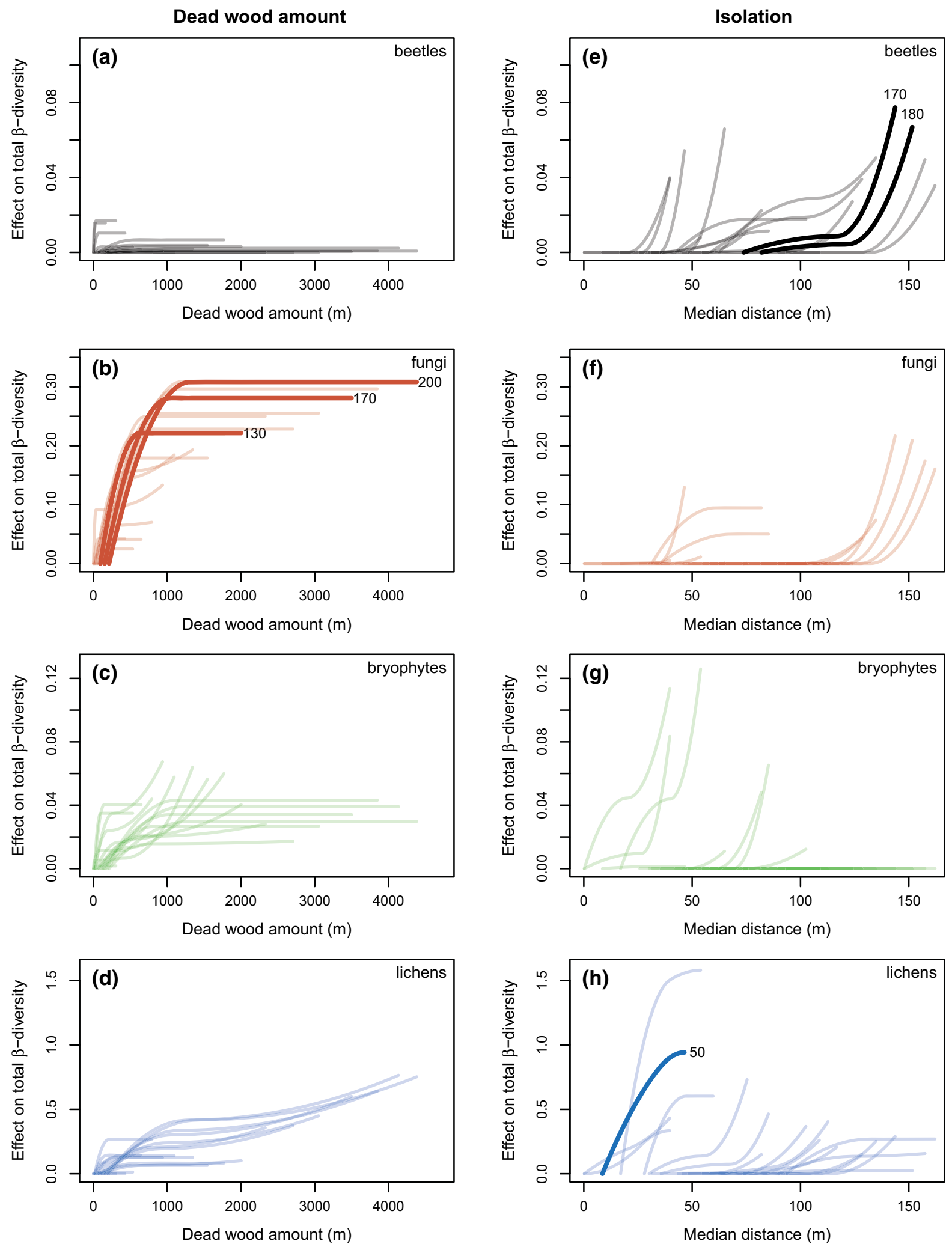
4Fig. 4 Results of generalized dissimilarity modeling from the small models for the four species groups: beetles (a, e), fungi (b, f), bryophytes $(\mathbf{c}, \mathbf{g})$ and lichens $(\mathbf{d}, \mathbf{h})$. The shape of the curves (I-splines) indicates the effect of dead wood amount (summed length of dead wood pieces; left) and isolation (median distance of dead wood pieces to the plot center; right) along their gradients on changes in community composition (beta diversity). The strength of the effect is indicated by total curve height (for absolute values see Tables S10-S13). One line represents one spatial scale. Lines for each scale differ in their start/end and length on the $\mathrm{x}$-axis because the gradient of the variable depends on the scale (e.g. dead wood amount $50 \mathrm{~m}$ radius: $12.5-531.4 \mathrm{~m}, 100 \mathrm{~m}$ radius: $54.3-1344.0 \mathrm{~m}$ ). Bold lines are I-splines of amount or isolation when the variable was significant $(\mathrm{p}<0.05)$ on the respective scale (radius indicated next to the line). Note that the $y$-axis scale differs among species groups

of dead wood amount remained constant and positive from 20 to $200 \mathrm{~m}$ radius, while isolation showed no relationship with species richness on any scale. Many saproxylic beetle species are considered highly mobile, capable of flying longer distances to colonize new habitats, and are therefore considered unimpaired by dispersal limitations (Ranius 2006; Janssen et al. 2016; Komonen and Müller 2018). Besides having a scattered distribution, dead wood is an ephemeral and dynamic habitat (Saint-Germain et al. 2007; Jönsson et al. 2008; Caruso et al. 2010). Consequently, not every dead wood piece meets the ecological requirements of every species (e.g. tree species, dimension or decay stage) at all times (Grove 2002; Stokland et al. 2012). Beetles can actively direct their movements to detect suitable habitat, allowing for easier colonization of dead wood within their movement range and beyond their immediate surroundings (Jonsson and Nordlander 2006; Vandekerkhove et al. 2011). Yet, depending on the stability of the respective suitable habitats (from stable cavities to more ephemeral fresh dead wood) different saproxylic beetle guilds were shown to be affected by landscape structure on different scales (Percel et al. 2019). Our results should therefore not lead to the conclusion that the spatial distribution of dead wood in the landscape is never important for saproxylic beetles. Negative effects may occur on larger spatial scales than those included in this study (Sverdrup-Thygeson et al. 2014) and/or for species with lower dispersal abilities (e.g. some red listed species: Brunet and Isacsson 2009; Rossi de Gasperis et al. 2016).
In contrast to the patterns observed for beetles, the significant relationship between dead wood amount and species richness of fungi, bryophytes and lichens disappeared on larger spatial scales in our study (radius $>60 \mathrm{~m}$ ). Instead, isolation showed a negative correlation with the species richness of these three species groups. This result contradicts the habitat amount hypothesis and suggests that the importance of habitat amount is scale dependent and that isolation is more important on larger scales. These species groups are considered sessile but disperse passively through propagules (lichens and bryophytes) or spores (fungi, bryophytes and lichens), which in principal enables airborne long-distance dispersal (Kallio 1970; Frahm 2007; Lönnell et al. 2014; Gjerde et al. 2015; Ronnås et al. 2017; Abrego et al. 2018; Komonen and Müller 2018). One could therefore expect that these species groups are not dispersal limited. However, it has been shown for fungi that spores principally disperse in the vicinity of sporulating fruiting bodies, because spore density rapidly decreases with increasing distance (Gregory 1945; Nordén and Larsson 2000; Edman et al. 2004; Norros et al. 2012). High spore densities up to around $100 \mathrm{~m}$ (Nordén and Larsson 2000; Norros et al. 2012) increase the chances that spores land on a suitable dead wood resource, if one is present. Similarly, dispersal limitations on the local scale have been found for various bryophyte and lichen species, probably because the vegetative propagules are often dispersal limited and settle mostly close to the source (Löbel et al. 2006; Werth et al. 2006; Scheidegger and Werth 2009; Lönnell et al. 2014). This could explain the negative relationship between species richness and isolation on the larger scales of this study. Still, species richness of bryophytes has been found to have a stronger response to habitat/source amount in the landscape than to the distance to the next source, probably due to a higher spore background level (Hylander 2009; Sundberg 2013). Conservation measures for promoting species richness of multiple taxonomic groups with different dispersal strategies and abilities should thus consider the amount of dead wood, as well as its spatial distribution in the landscape.

The response of community composition to dead wood amount and isolation was less clear. Even though it is known that forest variables influence community composition of the four species groups studied here (Löbel et al. 2006; Tinya et al. 2009; 
Raabe et al. 2010; Gossner et al. 2013; Vodka and Cizek 2013; Heilmann-Clausen et al. 2014), we could not explain most of the variance in the compositional dissimilarity (Tables 2, S9). Overall, we could not confirm our assumption that an increasing amount of dead wood would lead to different species assemblages. Such a pattern was only seen for fungi on three spatial scales (Fig. 4b) and the total deviance explained by the GDMs stayed low also on these scales (max. 6\%). Wood-inhabiting fungi often show over-dispersed community assemblages (Bässler et al. 2014) and therefore more dissimilarities between communities compared with other species groups, e.g. bryophytes (Heilmann-Clausen et al. 2005). This might be explained by strong competition between fungi in single dead wood pieces, with the consequence that only a few species build fruiting bodies (Heilmann-Clausen and Christensen 2004; Fukami et al. 2010; Roth et al. 2019). Probably due to these processes, other studies on wood-inhabiting fungi likewise did not show a relationship between local dead wood amount and community composition (Krah et al. 2018) or changes in composition 10 years after dead wood enrichment (Roth et al. 2019). In contrast, Raabe et al. (2010) found an effect of local dead wood amount on the community composition of epixylic bryophytes, and the models they used managed to explain $21 \%$ of the variance, a value our models did not reach. Besides dead wood amount, also isolation could not be identified as having a strong influence on community composition, being only significant on a few scales and lacking consistent patterns. For saproxylic beetles the findings of a previous study in Sihlwald forest, where community composition changed with connectivity (nearest-neighbor distance) but not with total dead wood volume (Schiegg 2000), were partly supported by our results. The effect of isolation was indeed greater than that of dead wood amount on most scales. Nevertheless, this finding should not be overrated, as the effect was only significant on two scales and not consistent. The absence of strong effects explaining community composition in this study might be a consequence of the spatial scales we studied (20-200 $\mathrm{m}$ radius). On larger scales it has previously been shown that, for example, the community composition of saproxylic beetles differed along a gradient of the proportion of old forest within 1,2 and $3 \mathrm{~km}$ (Olsson et al. 2012).
Further, Sihlwald forest is still very homogeneous, as it is a young forest reserve in the optimum stage of forest succession. Diversity of dead wood (e.g. different decay stages), which is important for the community composition of saproxylic species, might thus still be low. On the stand scale, differences in species assemblages caused by larger dead wood amounts might therefore only be found during a short time period after fresh dead wood is created, when early colonizers appear (Komonen et al. 2014). Hilmers et al. (2018) showed that assemblages of many species groups (including beetles, fungi, bryophytes and lichens) change along a forest succession gradient, with the most unique species appearing during early and/or late successional forest stages. Changes in community composition therefore might have a stronger relationship with forest variables and dead wood when the forest becomes more heterogeneous and gradients more pronounced.

\section{Conclusions}

Regarding the habitat amount hypothesis, selection of the 'appropriate' scale still remains one of the largest challenges (Fahrig 2013). While habitat amount, but not isolation, was important for all of the four investigated species groups (saproxylic beetles, wood-inhabiting fungi, and epixylic bryophytes and lichens) on small scales, the inverse pattern occurred on larger spatial scales for three of the species groups (fungi, bryophytes and lichens). Although previous studies have suggested that the spatial scales at which habitat amount and isolation affect species richness may differ, we present evidence that such patterns may be a widespread phenomenon. Importantly, if we had strictly followed the recommendations of Fahrig (2013) by choosing the radius with the strongest relationship between species richness and habitat amount as the 'local landscape', we would have incorrectly inferred the complete absence of isolation effects. Further, our findings demonstrate that patterns valid for one species group cannot automatically be projected onto other species groups, even though they use the same habitat.

Our results on the effects of dead wood amount and its spatial distribution can be of help for the conservation of saproxylic species in forest ecosystems. Based on our findings, the priority should be given to 
increasing the quantity of dead wood. In managed forests, one way this can be achieved is through retaining tree crowns after logging. When establishing new protected areas like forest reserves in formerly managed forests, targeted measures enhancing dead wood quantities can speed up the restoration process. Acknowledging that the spatial arrangement of dead wood already affects species richness within a forest reserve like the Sihlwald, it should be considered where applicable. A broad application of such measures will lead to the enhancement and even distribution of dead wood on both the forest and the landscape scale, increasing the availability of this important habitat for forest biodiversity.

Acknowledgements We thank the ranger team from Sihlwald (Nicole Aebli, Christoph Spuler, Emanuel Uhlmann and Thomas Wäckerle) for their support during fieldwork and the field teams of the forest inventory. Further, we thank Reik Leiterer for creating the first version of the dead wood map. This study was funded by the Federal Office for the Environment (FOEN) as part of the program "Pilotprojekt zur Förderung der ökologischen Infrastruktur in Pärken" and the Wildnispark Zurich foundation.

Open Access This article is licensed under a Creative Commons Attribution 4.0 International License, which permits use, sharing, adaptation, distribution and reproduction in any medium or format, as long as you give appropriate credit to the original author(s) and the source, provide a link to the Creative Commons licence, and indicate if changes were made. The images or other third party material in this article are included in the article's Creative Commons licence, unless indicated otherwise in a credit line to the material. If material is not included in the article's Creative Commons licence and your intended use is not permitted by statutory regulation or exceeds the permitted use, you will need to obtain permission directly from the copyright holder. To view a copy of this licence, visit http://creativecommons.org/licenses/by/4.0/.

Funding Open access funding provided by Bern University of Applied Sciences.

\section{References}

Abrego N, Norros V, Halme P, Somervuo P, Ali-Kovero H, Ovaskainen O (2018) Give me a sample of air and I will tell which species are found from your region: molecular identification of fungi from airborne spore samples. Mol Ecol Resour 18:511-524

Aude E, Poulsen RS (2000) Influence of management on the species composition of epiphytic cryptogams in Danish Fagus forests. Appl Veg Sci 3:81-88

Barton K (2018) Package "MuMIn": multi-model inference
Baselga A, Orme D, Villeger S, De Bortoli J, Maintainer FL (2017) Package 'betapart': partitioning beta diversity into turnover and nestedness components

Bässler C, Ernst R, Cadotte M, Heibl C, Müller J (2014) Nearto-nature logging influences fungal community assembly processes in a temperate forest. J Appl Ecol 51:939-948

Boch S, Prati D, Hessenmöller D, Schulze ED, Fischer M (2013) Richness of lichen species, especially of threatened ones, is promoted by management methods furthering stand continuity. PLoS ONE. https://doi.org/10.1371/journal.pone. 0055461

Böhl J, Brändli UB (2007) Deadwood volume assessment in the third Swiss National Forest Inventory: methods and first results. Eur J For Res 126:449-457

Bosco L, Wan HY, Cushman SA, Arlettaz R, Jacot A (2019) Separating the effects of habitat amount and fragmentation on invertebrate abundance using a multi-scale framework. Landsc Ecol 34:105-117

Brändli K, Stillhard J, Hobi M, Brang P (2020) Waldinventur 2017 im Naturerlebnispark Sihlwald. Eidg. Forschungsanstalt WSL, Birmensdorf

Brang P, Heiri C, Bugmann H (2011) Waldreservate. 50 Jahre natürliche Waldentwicklung in der Schweiz. Haupt, Bern

Brunet J, Isacsson G (2009) Restoration of beech forest for saproxylic beetles-effects of habitat fragmentation and substrate density on species diversity and distribution. Biodivers Conserv 18:2387-2404

Brunet J, Fritz Ö, Richnau G (2010) Biodiversity in European beech forests-a review with recommendations for sustainable forest management. Ecol Bull 53:77-94

Bryant D, Nielsen D, Tangley L (1997) The last frontier forests: ecosystems \& economies on the edge. World Resources Institute, Washington D.C.

Caruso A, Thor G, Snäll T (2010) Colonization-extinction dynamics of epixylic lichens along a decay gradient in a dynamic landscape. Oikos 119:1947-1953

De Camargo RX, Boucher-Lalonde V, Currie DJ (2018) At the landscape level, birds respond strongly to habitat amount but weakly to fragmentation. Divers Distrib. https://doi. org/10.1111/ddi.12706

Eckelt A, Müller J, Bense U, Brustel H, Bußler H, Chittaro Y, Cizek L, Frei A, Holzer E, Kadej M, Kahlen M (2018) "Primeval forest relict beetles" of Central Europe: a set of 168 umbrella species for the protection of primeval forest remnants. J Insect Conserv 22:15-28

Edman M, Kruys N, Jonsson BG (2004) Local dispersal sources strongly affect colonization patterns of wood-decaying fungi on spruce logs. Ecol Appl 14:893-901

Evju M, Sverdrup-Thygeson A (2016) Spatial configuration matters: a test of the habitat amount hypothesis for plants in calcareous grasslands. Landsc Ecol 31:1891-1902

Fahrig L (2013) Rethinking patch size and isolation effects: the habitat amount hypothesis. J Biogeogr 40:1649-1663

Fahrig L (2017) Ecological Responses To Habitat Fragmentation Per Se. Annu Rev Ecol Evol Syst. https://doi.org/10. 1146/annurev-ecolsys-110316-022612

FAO (2010) Global forest resources assessment 2010. FAO, Rome

FOREST EUROPE (2015) State of Europe's forests 2015. Ministerial Conference on the Protection of Forests in Europe, Madrid 
Frahm J-P (2007) Diversity, dispersal and biogeography of bryophytes (mosses). In: Foissner W, Hawksworth DL (eds) Protist diversity and geographical distribution. Springer, Dordrecht, pp 43-50

Fukami T, Dickie IA, Paula Wilkie J, Paulus BC, Park D, Roberts A, Buchanan PK, Allen RB (2010) Assembly history dictates ecosystem functioning: evidence from wood decomposer communities. Ecol Lett 13:675-684

Gjerde I, Blom HH, Heegaard E, Sætersdal M (2015) Lichen colonization patterns show minor effects of dispersal distance at landscape scale. Ecography (Cop) 38:939-948

Gossner MM, Lachat T, Brunet J, Isacsson G, Bouget C, Brustel H, Brandl R, Weisser WW, Mueller J (2013) Current nearto-nature forest management effects on functional trait composition of saproxylic beetles in beech forests. Conserv Biol 27:605-614

Gregory PH (1945) The dispersion of air-borne spores. Trans Br Mycol Soc 28:26-72

Grove SJ (2002) Saproxylic insect ecology and the sustainable management of forests. Annu Rev Ecol Syst 33:1-23

Haddad NM, Gonzalez A, Brudvig LA, Burt MA, Levey DJ, Damschen EI (2016) Experimental evidence does not support the Habitat Amount Hypothesis. Ecography (Cop) 125:336-342

Halme P, Allen KA, Auninš A, Bradshaw RH, Brūmelis G, Čada V, Clear JL, Eriksson AM, Hannon G, Hyvärinen E, Ikauniece S (2013) Challenges of ecological restoration: lessons from forests in northern Europe. Biol Conserv 167:248-256

Heilmann-Clausen J, Christensen M (2004) Does size matter? On the importance of various dead wood fractions for fungal diversity in Danish beech forests. For Ecol Manag 201:105-117

Heilmann-Clausen J, Aude E, Christensen M (2005) Cryptogam communities on decaying deciduous wood-does tree species diversity matter? Biodivers Conserv 14:2061-2078

Heilmann-Clausen J, Aude E, van Dort K, Christensen M, Piltaver A, Veerkamp M, Walleyn R, Siller I, Standovár T, Òdor P (2014) Communities of wood-inhabiting bryophytes and fungi on dead beech logs in Europe-reflecting substrate quality or shaped by climate and forest conditions? J Biogeogr 41:2269-2282

Hilmers T, Friess N, Bässler C, Heurich M, Brandl R, Pretzsch H, Seidl R, Müller J (2018) Biodiversity along temperate forest succession. J Appl Ecol 55:2756-2766

Hylander K (2009) No increase in colonization rate of boreal bryophytes close to propagule sources. Ecology 90:160-169

Imesch N, Stadler B, Bolliger M, Schneider O (2015) Biodiversität im Wald: Ziele und Massnahmen. Vollzugshilfe zur Erhaltung und Förderung der biologischen Vielfalt im Schweizer Wald, Bundesamt für Umwelt, Bern

IPBES (2019) Summary for policymakers of the global assessment report on biodiversity and ecosystem services of the Intergovernmental Science-Policy Platform on Biodiversity and Ecosystem Services. In: Díaz S, Settele J, Brondízio ES, Ngo HT, Guèze M, Agard J, Arneth A, Balvanera P, Brauman KA, Butchart SHM, Chan KMA, Garibaldi LA, Ichii K, Liu J, Subramanian SM, Midgley GF, Miloslavich P, Molnár Z, Obura D, Pfaff A, Polasky S, Purvis A, Razzaque J, Reyers B, RoyChowdhury R, Shin
YZ, Visseren-Hamakers IJ, Willis KJ, Zayas CN (eds) IPBES secretariat, Bonn, Germany, p 56. https://doi.org/ 10.5281/zenodo.3553579

Janssen P, Cateau E, Fuhr M, Nusillard B, Brustel H, Bouget C (2016) Are biodiversity patterns of saproxylic beetles shaped by habitat limitation or dispersal limitation? A case study in unfragmented montane forests. Biodivers Conserv 25:1167-1185

Jonsson M, Nordlander G (2006) Insect colonisation of fruiting bodies of the wood-decaying fungus Fomitopsis pinicola at different distances from an old-growth forest. Biodivers Conserv 15:295-309

Jonsson BG, Kruys N, Ranius T (2005) Ecology of species living on dead wood-lessons for dead wood management. Silva Fenn 39:289-309

Jönsson MT, Edman M, Jonsson BG (2008) Colonization and extinction patterns of wood-decaying fungi in a boreal oldgrowth Picea abies forest. J Ecol 96:1065-1075

Kallio T (1970) Aerial distribution of the root-rot fungus Fomes annosus in Finland. Acta For Fenn 107:1-55

Komonen A, Müller J (2018) Dispersal ecology of deadwood organisms and connectivity conservation. Conserv Biol 32:535-545

Komonen A, Kuntsi S, Toivanen T, Kotiaho JS (2014) Fast but ephemeral effects of ecological restoration on forest beetle community. Biodivers Conserv 23:1485-1507

Kormann UG, Hadley AS, Tscharntke T, Betts MG, Robinson WD, Scherber C (2018) Primary rainforest amount at the landscape scale mitigates bird biodiversity loss and biotic homogenization. J Appl Ecol 55:1288-1298

Krah FS, Seibold S, Brandl R, Baldrian P, Müller J, Bässler C (2018) Independent effects of host and environment on the diversity of wood-inhabiting fungi. J Ecol 106:1428-1442

Lachat T, Wermelinger B, Gossner MM, Bussler H, Isacsson G, Müller J (2012) Saproxylic beetles as indicator species for dead-wood amount and temperature in European beech forests. Ecol Indic 23:323-331

Landolt E, Bäumler B, Ehrhardt A, Hegg O, Klötzli F, Lämmler W, Nobis M, Rudmann-Maurer K, Schweingruber FH, Theurillat JP, Urmi E (2010) Flora indicative. Ökologische Zeigerwerte und biologische Kennzeichen zur Flora der Schweiz und der Alpen. Haupt, Bern

Lassauce A, Paillet Y, Jactel H, Bouget C (2011) Deadwood as a surrogate for forest biodiversity: meta-analysis of correlations between deadwood volume and species richness of saproxylic organisms. Ecol Indic 11:1027-1039

Leiterer R, Mücke W, Morsdorf F, Hollaus M, Pfeifer N, Schaepman ME (2013) Flugzeuggestütztes Laserscanning für ein operationelles Waldstrukturmonitoring. PFG 3:173-184

Lindgren JP, Cousins SAO (2017) Island biogeography theory outweighs habitat amount hypothesis in predicting plant species richness in small grassland remnants. Landsc Ecol 32:1895-1906

Löbel S, Snäll T, Rydin H (2006) Species richness patterns and metapopulation processes-evidence from epiphyte communities in boreo-nemoral forests. Ecography (Cop) 29:169-182

Lönnell N, Jonsson BG, Hylander K (2014) Production of diaspores at the landscape level regulates local 
colonization: an experiment with a spore-dispersed moss. Ecography (Cop) 37:591-598

MacArthur RH, Wilson EO (1967) The theory of island biogeography. Princeton University Press, Princeton

Manion G, Lisk M, Ferrier S, Nieto-Lugilde D, Mokany K, Fitzpatrick MC (2018) Package "gdm": generalized dissimilarity modeling version

Margules CR, Pressey RL (2000) Systematic conservation planning. Nature 405:243-253

Martikainen P, Siitonen J, Punttila P, Kaila L, Rauh J (2000) Species richness of Coleoptera in mature managed and oldgrowth boreal forests in southern Finland. Biol Conserv 94:199-209

Mason F, Zapponi L (2016) The forest biodiversity artery: towards forest management for saproxylic conservation. iForest 9:205-216

MCPFE (2003) State of Europe's forests - the MCPFE report on sustainable forest management in Europe. Ministerial Conference on the Protection of Forests in Europe, Vienna

Melo GL, Sponchiado J, Cáceres NC, Fahrig L (2017) Testing the habitat amount hypothesis for South American small mammals. Biol Conserv 209:304-314

Merckx T, de Miranda MD, Pereira HM (2019) Habitat amount, not patch size and isolation, drives species richness of macro-moth communities in countryside landscapes. J Biogeogr. https://doi.org/10.1111/jbi.13544

Moeser D, Morsdorf F, Jonas T (2015) Novel forest structure metrics from airborne LiDAR data for improved snow interception estimation. Agric For Meteorol 208:40-49

Müller J, Bütler R (2010) A review of habitat thresholds for dead wood: a baseline for management recommendations in European forests. Eur J For Res 129:981-992

Müller J, Bußler H, Kneib T (2008) Saproxylic beetle assemblages related to silvicultural management intensity and stand structures in a beech forest in Southern Germany. J Insect Conserv 12:107-124

Müller J, Brunet J, Brin A, Bouget C, Brustel H, Bussler H, Foerster B, Isacsson G, Koehler F, Lachat T, Gossner MM (2013) Implications from large-scale spatial diversity patterns of saproxylic beetles for the conservation of European Beech forests. Insect Conserv Divers 6:162-169

Müller J, Boch S, Blase S, Fischer M, Prati D (2015) Effects of forest management on bryophyte communities on deadwood. Nov Hedwigia 100:423-438

Nordén B, Larsson KH (2000) Basidiospore dispersal in the oldgrowth forest fungus Phlebia centrifuga (Basidiomycetes). Nord J Bot 20:215-219

Norros V, Penttilä R, Suominen M, Ovaskainen O (2012) Dispersal may limit the occurrence of specialist wood decay fungi already at small spatial scales. Oikos 121:961-974

Olsson J, Johansson T, Jonsson BG, Hjältén J, Edman M, Ericson L (2012) Landscape and substrate properties affect species richness and community composition of saproxylic beetles. For Ecol Manag 286:108-120

Paillet Y, Bergès L, Hjältén J, Ódor P, Avon C, BernhardtRömermann MA, Bijlsma RJ, De Bruyn LU, Fuhr M, Grandin UL, Kanka R (2010) Biodiversity differences between managed and unmanaged forests: meta-analysis of species richness in Europe. Conserv Biol 24:101-112
Percel G, Laroche F, Bouget C (2019) The scale of saproxylic beetles response to landscape structure depends on their habitat stability. Landsc Ecol 34:1905-1918

Pulsford SA, Lindenmayer DB, Driscoll DA (2017) Reptiles and frogs conform to multiple conceptual landscape models in an agricultural landscape. Divers Distrib 23:1408-1422

R Core Team (2018) R: a language and environment for statistical computing. R Foundation for Statistical Computing, Vienna, Austria. https://www.R-project.org/

Raabe S, Müller J, Manthey M, Dürhammer O, Teuber U, Göttlein A, Förster B, Brandl R, Bässler C (2010) Drivers of bryophyte diversity allow implications for forest management with a focus on climate change. For Ecol Manag 260:1956-1964

Ranius T (2006) Measuring the dispersal of saproxylic insects: a key characteristic for their conservation. Popul Ecol 48:177-188

Rigling A, Schaffer HP (eds) (2015) Waldbericht 2015. Zustand und Nutzung des Schweizer Waldes. Bundesamt für Umwelt, Bern. Eidg. Forschungsanstalt WSL, Birmensdorf

Ripley B, Venables B, Bates DM, Hornik K, Gebhardt A, Firth D (2018) Package "MASS": support functions and datasets for Venables and Ripley's MASS

Rockström J, Steffen W, Noone K, Persson Å, Chapin FS III, Lambin E, Lenton TM, Scheffer M, Folke C, Schellnhuber HJ, Nykvist B (2009) Planetary boundaries: exploring the safe operating space for humanity. Ecol Soc 14:472-475

Ronnås C, Werth S, Ovaskainen O, Várkonyi G, Scheidegger C, Snäll T (2017) Discovery of long-distance gamete dispersal in a lichen-forming ascomycete. New Phytol 216:216-226

Rossi de Gasperis S, Passacantilli C, Redolfi De Zan L, Carpaneto GM (2016) Overwintering ability and habitat preference of Morimus asper: a two-year mark-recapture study with implications for conservation and forest management. J Insect Conserv 20:821-835

Roth N, Doerfler I, Bässler C, Blaschke M, Bussler H, Gossner MM, Heideroth A, Thorn S, Weisser WW, Müller J (2019) Decadal effects of landscape-wide enrichment of dead wood on saproxylic organisms in beech forests of different historic management intensity. Divers Distrib 25:430-441

Saint-Germain M, Drapeau P, Buddle CM (2007) Host-use patterns of saproxylic phloeophagous and xylophagous Coleoptera adults and larvae along the decay gradient in standing dead black spruce and aspen. Ecography (Cop) 30:737-748

Sala OE, Chapin FS, Armesto JJ, Berlow E, Bloomfield J, Dirzo R, Huber-Sanwald E, Huenneke LF, Jackson RB, Kinzig A, Leemans R (2000) Global biodiversity scenarios for the year 2100. Science 287:1770-1774

Scheidegger C, Werth S (2009) Conservation strategies for lichens: insights from population biology. Fungal Biol Rev 23:55-66

Schiegg K (2000) Effects of dead wood volume and connectivity on saproxylic insect species diversity. Écoscience 7:290-298

Schleppi P, Conedera M, Sedivy I, Thimonier A (2007) Correcting non-linearity and slope effects in the estimation of the leaf area index of forests from hemispherical photographs. Agric For Meteorol 144:236-242

Seibold S, Bässler C, Brandl R, Gossner MM, Thorn S, Ulyshen MD, Müller J (2015) Experimental studies of dead-wood 
biodiversity - a review identifying global gaps in knowledge. Biol Conserv 191:139-149

Seibold S, Bässler C, Brandl R, Fahrig L, Förster B, Heurich M, Hothorn T, Scheipl F, Thorn S, Müller J (2017) An experimental test of the habitat-amount hypothesis for saproxylic beetles in a forested region. Ecology 98:1613-1622

Steffen W, Richardson K, Rockström J, Cornell SE, Fetzer I, Bennett EM, Biggs R, Carpenter SR, De Vries W, De Wit CA, Folke C (2015) Planetary boundaries: guiding human development on a changing planet. Science 348:1217-1217. https://doi.org/10.1126/science.aaa9629

Stofer S, Bergamini A, Aragon G, Carvalho P, Coppins BJ, Davey S, Dietrich M, Farkas E, Kärkkäinen K, Keller C, Lökös L (2006) Species richness of lichen functional groups in relation to land use intensity. Lichenol 38:331-353

Stokland JN, Siitonen J, Jonsson BG (2012) Biodiversity in dead wood. Cambridge University Press, Cambridge

Sundberg S (2013) Spore rain in relation to regional sources and beyond. Ecography (Cop) 36:364-373

Sverdrup-Thygeson A, Gustafsson L, Kouki J (2014) Spatial and temporal scales relevant for conservation of deadwood associated species: current status and perspectives. Biodivers Conserv 23:513-535

Thimonier A, Sedivy I, Schleppi P (2010) Estimating leaf area index in different types of mature forest stands in Switzerland: a comparison of methods. Eur J For Res 129:543-562

Tinya F, Márjaligeti S, Király I, Németh B, Ódor P (2009) The effect of light conditions on herbs, bryophytes and seedlings of temperate mixed forests in Örség, Western Hungary. Plant Ecol 204:69-81

Tscharntke T, Tylianakis JM, Rand TA, Didham RK, Fahrig L, Batáry P, Bengtsson J, Clough Y, Crist TO, Dormann CF,
Ewers RM (2012) Landscape moderation of biodiversity patterns and processes-eight hypotheses. Biol Rev 87:661-685

Vandekerkhove K, De Keersmaeker L, Walleyn R, Köhler F, Crevecoeur L, Govaere L, Thomaes A, Verheyen K (2011) Reappearance of old-growth elements in lowland woodlands in northern Belgium: do the associated species follow? Silva Fenn 45:909-936

Vilén T, Gunia K, Verkerk PJ, Seidl R, Schelhaas MJ, Lindner M, Bellassen V (2012) Reconstructed forest age structure in Europe 1950-2010. For Ecol Manag 286:203-218

Vodka Š, Cizek L (2013) The effects of edge-interior and understorey-canopy gradients on the distribution of saproxylic beetles in a temperate lowland forest. For Ecol Manag 304:33-41

Watling JI, Arroyo-Rodríguez V, Pfeifer M, Baeten L, BanksLeite C, Cisneros LM, Fang R, Hamel-Leigue AC, Lachat T, Leal IR, Lens L (2020) Support for the habitat amount hypothesis from a global synthesis of species density studies. Ecol Lett 23:674-681

Werth S, Wagner HH, Gugerli F, Holderegger R, Csencsics D, Kalwij JM, Scheidegger C (2006) Quantifying dispersal and establishment limitation in a population of an epiphytic lichen. Ecology 87:2037-2046

Wirth V (2010) Ökologische Zeigerwerte von Flechten erweiterte und aktualisierte Fassung. Herzogia 23:229-248

Zellweger F, Baltensweiler A, Schleppi P, Huber M, Küchler M, Ginzler C, Jonas T (2019) Estimating below-canopy light regimes using airborne laser scanning: an application to plant community analysis. Ecol Evol 9:9149-9159

Publisher's Note Springer Nature remains neutral with regard to jurisdictional claims in published maps and institutional affiliations. 